\title{
Retracted: Information Fields Navigation with Piece-Wise Polynomial Approximation for High-Performance OFDM in WSNs
}

\author{
Mathematical Problems in Engineering \\ Received 26 January 2015; Accepted 26 January 2015 \\ Copyright (C) 2015 Mathematical Problems in Engineering. This is an open access article distributed under the Creative Commons \\ Attribution License, which permits unrestricted use, distribution, and reproduction in any medium, provided the original work is \\ properly cited.
}

The paper titled "Information Fields Navigation with PieceWise Polynomial Approximation for High-Performance OFDM in WSNs" [1], published in Mathematical Problems in Engineering, has been retracted upon the authors' request, as they found that there are some wrong results in their paper.

\section{References}

[1] W. Wei, P. Shen, Y. Zhang, and L. Zhang, "Information fields navigation with piece-wise polynomial approximation for highperformance OFDM in WSNs," Mathematical Problems in Engineering, vol. 2013, Article ID 901509, 9 pages, 2013. 